\title{
Roundtable and Discussion: Americans in the South Pacific
}

\author{
Edited by Therese-Marie Meyer, Danielle Norberg, \\ Henriette von Holleuffer \& Oliver Haag
}

Prof. Dr. Cassandra Pybus (University of Sydney)

One of Australia's most famous historians, Cassandra Pybus opened this field of global research with her seminal publication on escaped American slaves in the First Fleet, Black Founders (2006).

Prof. Dr. Andrew O'Shaughnessy (Saunders Director of the Robert H. Smith International Center for Jefferson Studies, Monticello; University of Virginia)

Andrew O'Shaughnessy is one of America's foremost military historians. His study The Men Who Lost America (2014) examines the British military administration during and after the War of Independence.

Prof. Dr. Jennifer L. Anderson (Stony Brook University/ State University of New York) In her study of the early colonial American trade in the Caribbean and South Pacific, Mahogany (2012), Anderson explored the American drive for luxury goods and their social, environmental and political impact.

Chair: Dr. Therese-Marie Meyer

Transcript: Danielle Norberg

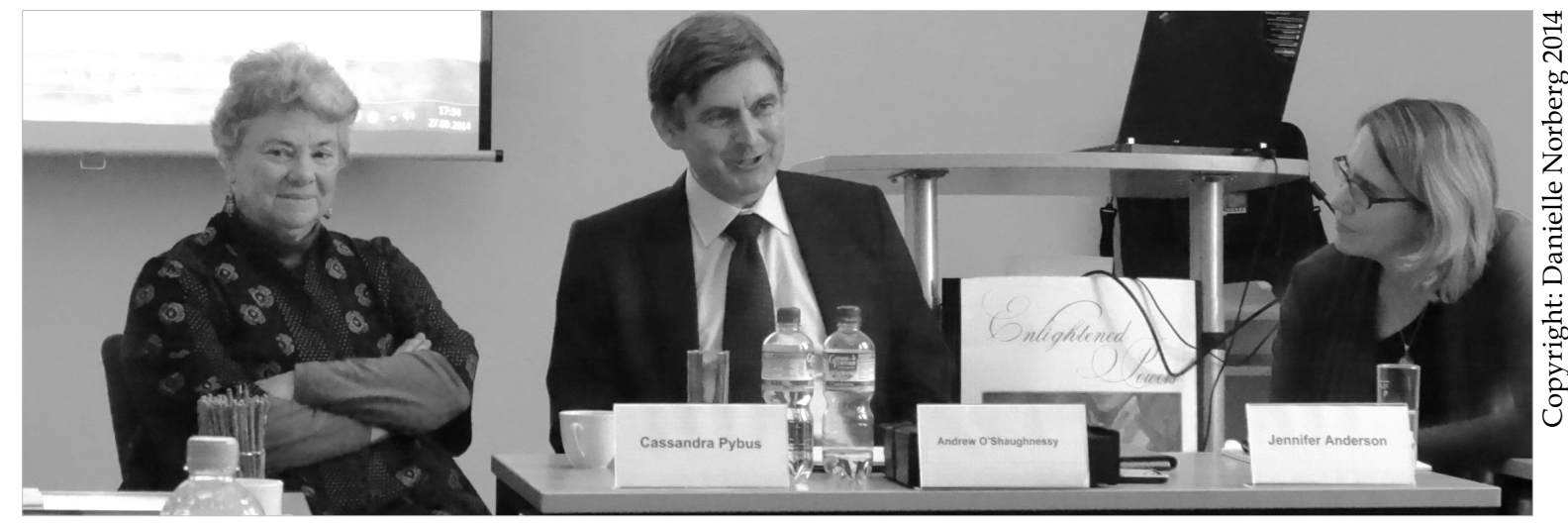

Cassandra Pybus: I do want to begin by making the point because it's not a point that is often made: that New South Wales - Port Jackson and the Colony of New South Wales - is a product of America, it's a product of the American Revolution, in many ways which we can explore. But I think that Australianists have these core [beliefs], a sort of narrow focus of the Colony and the Empire - not even the Empire - the Colony and the imperial part of the Empire and seeing everything in terms of that - you know - that passageway. Not even really paying that much attention to the long trip and the various routes that it took to get there. But for all the talk about how this was part of the Second British Empire and, you know, whatever strategic possibilities this place at the bottom of the world may have had, at the time this was 
not figuring in the way people thought. What they were thinking of is where they could get rid of their 'riff-raff' now that they couldn't send them to America. And so this place that Captain Cook had discovered, or bumped into, at the bottom of the world was the place that they settled upon. And they would not have done that if America had remained a richer market, they would not have had any reason to do that. And this is not to say that Australia wouldn't have turned into a nation of some kind, probably French, at a later date, but I think it's - we can thank the fact that it turned out to be a nation born of the flotsam and jetsam of London street life. We can owe it to the American Revolution, yes. And so I'll just open with that.

Jennifer Anderson: Great. I am going to talk a little bit about the characters that have been introduced already, the American whalers. But before I do that I want to thank first of all Tess for the invitation, it's been wonderful to visit, I have enjoyed meeting everybody that I have had a chance to talk to. And I also want to say that it is really a treat and an honour for me to get to participate in a panel with two scholars who have, to my mind, really transformed the way we think about and teach in particular the American Revolution. I certainly talk about it with my students as a much more global event, often to their disconsternation. I don't even think - I made a new word up - to their consternation, to their dismay, to their surprise, to learn that there is a much larger context than those thirteen original colonies that are often emphasized. So there are a couple of themes that sort of have emerged from our discussions today that I am going to pick up on with regard to the American whalers, thinking about connections between the global and the local, thinking about modes and knowledge production in this so-called Age of Enlightenment, as well as the way in which we see people on the move, ideas on the move, and increasingly natural materials as they are increasingly commodified being put on the move.

In my case, it had been the American whalers who'd bring all of these threads together in interesting, sometimes unexpected ways. So when I was thinking about how to talk about this I immediately realized I needed a map to kind of quickly help put the Australia piece of this into the larger context because American whaling really begins as a very local affair. In fact, in my very neighbourhood, in Long Island, along the coastal regions of New York and New England, where, when the very first European settlers arrived, one of the things they observed were whales disporting themselves in the waters right off the coast, and they observed native Americans hunting them oftentimes, salvaging whales that had been washed up on the shore and then also doing some whaling from small boats, canoes, very close to the coast. And in the earliest land negotiations with Native peoples access to whales (which the colonists talk about as being washed up by Providence, a gift from Providence) how those are going to be disposed of, is negotiated in some of the earliest land treaties, along discussion of land.

A great example of this is Wyandanch, a Sachem, who negotiates for part of Long Island with Lion Gardiner, one of the earliest settlers. In 1659 they set up a treaty where he - Gardiner - is granted access to all the whales that wash up except for the tail and the fluke, the fins which the Indians retain the rights to. And that begins as an interesting negotiation between almost equals. But very quickly, in the end of the eighteenth, beginning of the nineteenth century, you see that balance of power shifting as Native people are increasingly pushed out of the lands that they had traditionally held and come into colonial relationships with the English and, to some 
degree, the Dutch, in New York, in ways that push, and begin to increasingly preclude the kind of subsistence agriculture and hunting and gathering particularly along coastal regions. And, of course, access to whales, which traditionally they had kept a hand in. You see this relationship transformed in the way in which the English tap into the knowledge that Native people had about the whale species in and around the coastal waters and their expertise in the labour of catching whales and harvesting them.

You might think that the English would quickly try to assimilate this knowledge - and to some degree they do - but what is very interesting is that in many of the communities along Long Island and up along the Coast area, Connecticut and right up through Massachusetts, the Native people continued to be intricately involved in whaling, providing part of the labour. And soon they are supplemented by enslaved Africans, who are also providing part of this mixed labour force. So you have Native people working alongside enslaved Africans, working alongside the sons of many of the middle-level New England families. And a place like Nantucket is probably the most famous whaling community because it was pretty far offshore and there really was no other enterprise. They can't cultivate the land there, they cultivate this production of oil derived from the sea, so to speak. The thread that has to be woven through this story is one of people's ecological relationship to this natural resource because as they are hunting more and more whales, the whales become scarcer, they become savvier about where to go. They get to change their migration patterns, and it is an ongoing project of knowledge production as whalers begin to learn and adapt and increasingly go deeper and deeper into the Atlantic in search of, initially, the species they are familiar with.

So the people that really begin to know the ocean, the Atlantic Ocean, best are these men out there in pursuit of the Leviathan. And you see them basically expanding out from coastal zones through the North Atlantic, where some Europeans had done whaling earlier, and then down the coast of Brazil, and if you can kind of imagine in your mind's eye their sailing vessels coming down, hitting up the whale feeding grounds along the eastern coast of Brazil, that becomes in the 1780s a major area where people are hunting sperm-whale in particular, used for high-quality lighting and oil. And then as whalers begin to tune into the beginning of the China trade and reports come back about whales being spotted in those waters, they work their way down under the tip of South America and begin working their way up the coastal zones of Chile and Peru. And then expanding out further and further into the Pacific, first into the waters in and around Australia, right?

There is this very interesting period, that Cassandra has been looking at. The main outsiders that are going to the trouble to traverse these waters are these whalers. And they are stopping off on and around the South Sea Islands, in New Zealand, in Sydney and later other smaller ports as well and basically beginning various kinds of exchanges. The rum, of course, as the classic example, for what do they have to sell? They quickly figure out what is going to be merchantable. But on some of the South Sea Islands we see these Westerners as the first to encounter South Sea Islanders: It was a pretty rough crowd they probably encountered, bringing with them diseases and other kinds of social problems that - as you know - have long-term consequences. And the other thing that I think is very fascinating is: We also see the influences going in more than one direction. So there are very interesting accounts 
of Native American whalers who jump ship and stay and in some cases actually intermarry. We do not really have numbers yet to quantify this, and there is actually a lot of scholarship going on right now to try and get a better sense of how many of these Native American whalers were there and how many enslaved Africans. Those coming out of Nantucket actually were free, there was a Quaker community. So one of the things we see, as the whalers go into the Pacific, is that the ships get larger and the crews get bigger. It means more men are required and so it tends to be more and more inexperienced people. [Also] more and more drawing from the diaspora of the Pacific region itself. So we get Hawaiians and eventually South Sea Islanders on the ships, working alongside these New England Indians and enslaved Africans or free black men. And because they are the ones with experience they are able to gain rank and status sometimes aboard ship, sometimes gaining officer status, and in a few cases actually becoming captains although that was rare. But that was made possible by the fact that there is this incredibly cosmopolitan work force, in which their expertise becomes increasingly valuable.

The other thing I would say about that transfer is that it's not just the fact that they are able to make a successful voyage - although it becomes increasingly difficult to do that as the whales begin to get overhunted even in the vast Pacific - but you also see whalers contributing to a larger project of knowledge production. For example, beginning even with Franklin in the Atlantic when he was trying to map the Gulf Stream. One of his sources of information were people who had been out there traversing that and learning the currents and patterns. Similarly in the Pacific - whalers provide an information source to scientists and others. So the last two things I'd mention before my time is up is... what is going on in terms of ongoing research. We are really at the moment at a point where we are trying to document and quantify a little bit better how many of these whalers end[ed] up staying. And there is a wonderful brand-new book I just got my hands on, by my friend and colleague Nancy Shoemaker: I can recommend this to you if it's a topic of interest, in which she draws together historic documents, basically trying to trace this development that I am sharing with you.

And then the last section focuses on whalers who intermarried in New Zealand with Maori women. And basically they became part of the community and [were] embraced and sometimes treated as persons of status which is such a different experience to what you described about free black men encountering in Australia. But it is fascinating because those families with this Native American heritage, they go back to doing this kind of whaling that their families had done for generations before. Then as they settle in, the second generation continued to be whalers, and then they slowly shift from whaling over to sheep-herding. I think it is very fascinating that they are remembered in the oral histories that Nancy Shoemaker did with some of these families as being among the fastest, with greatest stamina and the hardiest of sheep-herders. That they could take the wool off a sheep in record-time and I thought after wrestling with whales in the Pacific, Australian sheep might be small gain. So I will finish with that.

Andrew O'Shaughnessy: Thank you. Well, I'd like to add my thanks to Doctor Meyer. This is tremendous, and I'd also like to thank the sponsors as well and the sponsor institutions. I have to say, I was particularly intrigued when she asked me to participate because she said she wanted me to speak about the connection between 
the American Revolution and the founding of Australia. And I had always felt intuitively that there was a connection but I had never found any material on the subject, and no one confirmed this to me until I met Cassandra Pybus. And she was the first to formally talk about the subject. But it is still not a subject that has been systematically studied. Cassandra has already discussed and suggested one connection. And that is the connection between maroonage and runaway slaves in Australia and the iconic bushman. And I heard a lot about this project while it was in inception. She was a fellow at Monticello and she did a wonderful article called: "Mr. Jefferson's Faulty Mathematics", in which she looked at the runaway slaves from Monticello and what had happened to them. It was called "Faulty Mathematics" because Jefferson much exaggerated the numbers of slaves who ran away, not just on his own plantation but in Virginia generally. She showed clearly: What was unusual about this phenomenon is that people were running away as families. It wasn't single men, they were leaving as units. This really was a case of self-emancipation. And then I was fortunate enough to go to Australia, where we co-hosted two conferences in two consecutive years, and to be sitting with Cassandra, drinking Martinis overlooking Sydney Harbour. And you had one of the great views in the world with the Sydney Opera House, and then suddenly the whole story became more meaningful because Cassandra started to describe Billy Blue and how he'd had the rights of the crossing of this harbour. And it all became much more meaningful and much more important.

I want to now just sketch out other links between the American Revolution and the founding of Australia. Remember this has not been much studied, but is one of certain subjects, I think, one would necessarily need to cover. One of you could write this book, yes, and it is remarkable to me that it hasn't been. Especially given the modern-day interest in Australia in the United States. But one of the first things that I think is quite striking is the fact that the exploration of the Pacific and Australia was coterminous with the preliminaries of the American Revolution. But even more remarkably, it continued during the war. Cook's third voyage occurred during the American Revolutionary War. And it was conducted by the British Navy. Now, the reason I find that really very remarkable is that the British Navy was overstretched at the time. This was the only war in the eighteenth century where they were outnumbered by the French and the Spanish Navy. And they were trying to convoy all of their ships. Their trade had to be convoyed because of American privatiers who I would liken really to militia at sea. Governors in the Caribbean said American privatiers were like fleas, they were everywhere and they necessitated the British protecting their trade.

The person responsible for these voyages was the Earl of Sandwich, he was the head of the Navy at the time. The official title was 'First Lord of the Admirality'. If you think you have heard the word 'sandwich' before, the snack, it is actually named after him because of his habit when he was working hard - or it has to be said, playing hard as well, he was a great gambler - of just putting meat between bread, and eating it. He was not leaving his table to go off and have a meal. But Sandwich was fascinated by exploration. It was very unusual because most aristocrats in this period did what was known as the 'Grand Tour of Europe'. The Grand Tour always consisted of a visit to France, but most significantly to Italy, largely to look at classical ruins. He instead did a tour of the Mediterranean, he got a yacht, 
and he visited places like Egypt, and he later wrote up descriptions. He was very early on interested in the Middle East and Egypt, and especially Turkey. And it was Sandwich who helped to be the patron of these voyages, who, for example, provided Joseph Banks, as the botanist, and who took a particular interest in the scientific information. Indeed, Sandwich after the war was the one who was really interested in documenting Cook's voyages and collecting the information and systematically publishing work on voyages and explorations. So that is the first connection that I think [is] important. This exploration continues actually during the war when the British Navy really could not afford the shipping.

The second is the role of convicts in the founding of Australia. Before the American Revolution, the convicts were going to America. This is often forgotten. We imagine that this is something that starts post the American Revolution. Some fifty thousand convicts went from England to America. Georgia was the last of the thirteen colonies to be settled and set up by the British. The man who set that up was James Edward Oglethorpe. He set it up as a penal colony. And it was very utopian: There was to be no slavery in its original charter, and the idea was to reform convicts who would be sent there and they would breed silkworm. That was the original plan. But another major destination was Pennsylvania, where incidentally a large number of the Moravians and German immigrants to America went. And Franklin famously decried the fact that Britain was sending its convicts. He said: "We should send our convicts and refuse to England".

Jennifer Anderson: And rattlesnakes.

Andrew O'Shaughnessy: And rattlesnakes.

\section{Laughter}

Andrew O'Shaughnessy: Then during the war, obviously, the convicts could not go to [America], so they were kept in prison ships along the Thames. And this is actually an Enlightenment idea, though we have heard all the horrors of how these people were treated. But we should remember this was an alternative to execution. In some ways it reinforced the criminal justice system because jurors were often unwilling to convict people if they knew that they were going to be hung or executed. But that was an enlightened idea: This was going to improve the penal system. In the immediate aftermath of the American Revolution, you get people like John Howard with new thinking about the criminal justice system, about prisons, and so this was regarded as being enlightened. Now Maya Jasanoff recently did a book called: Liberty's Exiles. And in it she talks about the lawless and the different places that they went abroad, and she has marvellous individual stories of where people went. But she argues that they created this spirit of 1783, the new Spirit of Empire.

The trouble with that argument is that the loyalists only really were dominant in the Bahamas and in Canada. They went in significant numbers to those countries. Elsewhere they were a very small minority and it is difficult to believe they really had a significant impact. If you really want to think about who was important from America, especially in Australia, it was the army officers who had served in America. And this is something you mentioned, Tess, which I thought remarkable, and Cassandra has mentioned, and I am sure you are influenced by examples like George Johnston. We know that a lot of people, a lot of the Army officers who served in Australia and Naval officers had served in America but nearly all of them had served in some 
capacity during the Revolutionary War, whether it was in the Caribbean or other islands. They had been affected by the American Revolution. The research still needs to be done as to the exact influence, i.e. that on those officers serving in Australia. ${ }^{1}$

But we do know enough about officers elsewhere to make what I think are some likely generalisations about Australia. The most famous British officer to serve in the Empire was Lord Charles Cornwallis. And Cornwallis - unlike all the other British generals who were largely discredited, and even if they had not been discredited, they had gone off into politics with the opposition parties, and had lost the support of George III. - he was one of the few whose career not only survived the Revolution, it was revitalised. And we heard that he suppressed the Great Irish Rebellion in 1798. But he twice served as Governor General of India, and you can make some generalisations about his service in America on the way that he conducted himself in South India. And in a way I believe that would also be true in Australia. But there were many more, for example, Archibald Campbell, who was the only British officer to recover an entire American state, he became governor of Madras. In Canada, Sir Guy Carlton, who becomes Lord Dorchester and returns to become Governor of [the British possessions with the exception of Newfoundland]. John Simcoe, who ran a regiment called the Queen's rangers, went back to command in lower [South Ontario]. Both of them detested the United States and were overtly hostile to the point of really almost trying to trigger a war.

Cornwallis is the one we know best, so I am going to give that example because it is quite clear, his time in America did indeed influence him. And one of the things that might surprise you is that the time spent in America and knowledge of the American Revolution did not cause the British to become more liberal. That was not the lesson that they took away from the American Revolution. Cornwallis, for example, one of the lessons he learned was that you don't want to let a colonial lead become too strong. Once a colonial lead has got used to governing and has participated in the role of governing, they can become confident enough to overthrow you. And most leaders of revolutions, in fact, come from a privileged class, including the Trotskyists and Leninists who came from a privileged class in leading the revolution. And one of the things that Cornwallis did in India, and he was regarded in Britain as a very enlightened figure, is he voted against all the policies that led to the American Revolution: He was one of only six people in the House of Lords to vote against the Stamp Act which was the first tax in America in 1765, and very few people in England at the time opposed it, but Cornwallis was [also] the first to start segregating the Indian Civil Service. So that only whites from England served in the higher positions of power.

It's remarkable, in the eighteenth century, that there had been a huge amount of racial intermixture, if you want to read a fun book on the subject, William Dalrymple wrote a book called White Mughals in which he describes these Englishmen with Indian wives, going native and wearing Indian costume. This was not frowned upon. But beginning with Cornwallis it becomes a much more segregated society. Cornwallis also learned a lot of military lessons from his time in America. He argued you must always keep your troops consolidated, the great error is to detach

1 See Therese-Marie Meyer, “'Stuck a Bayonet into the grave \& Renew'd their Oath': The American Revolution and the First Fleet", in: Maria O'Malley and Denys van Renen, eds., Beyond 1776: Globalizing the Cultures of the American Revolution. Charlottesville, Virginia: University of Virginia Press, 2018. 189-205. 
troops because he detached his army to the South where the main British army in New York had become surrounded.

It's Cornwallis, in fact, who really helps the British expand in India and to take much of the South of India. So he's really an important figure in that capacity. So I would say that the chief lesson in the American Revolution for the British was not to be more lenient. And not to be more flexible. They believed that the American Revolution had been caused, in fact, by allowing America to become too autonomous. The policies, the 1760s, the decision to tax America, these policies were in fact - and they are seen as enlightened policies at the time - to try to centralise, to rationalise the government of America. But they are also a result, in a sense, of the fact that Britain had already lost America. The British only had taken power over America. The British were trying - just before the American Revolution - to reassert their authority. Because in the earlier period, in the 1720s and -30s, British officials talked about "sanitary neglect, healthy neglect". Colonial leaders had really become responsible for much of the day-to-day government. Royal Governors were almost token figures because for any money they needed they had to go to the colonial assembly to have it voted. Hannah Arendt argues that the reason why the American Revolution was so successful, comparatively, the reason it did not end in military dictatorship, the reason that it did not end like a lot of South American rebellions, with constant revolutions, was that - thanks to the assemblies, those who had been in nursery as future statesmen, - Americans essentially had not had to reinvent the wheel: They had already been governing themselves in the first place. And that was what the British wanted to prevent in Australia.

Cassandra Pybus: Well, they certainly were very successful at it. And I mean, I have very little to add to that, that pretty well sums it up. I would say the influence of the American Revolution was really in that early period, when you have the people that I talked about who arrived on the First and the Second Fleet. Well, the First Fleet. By the time you start having, what I refer to as the rapacious 'riff-raff', who make up the officers of the New South Wales Corps, basically young officers buying their way into the army and the only regiment they can get into. They don't bring anything with them except, you know, for their venality and their desire to make good. And this does pretty well become a pattern in Australia. You asked a question about George Johnston and why he would come back. Well, what I was to suggest to remember: He comes back because - not only because that is the only place he is going to be a rich man - but he's got a family there, and his wife was a convict woman. He eventually married her, but I mean a lot of them did [marry their convict mistresses]. Marriage was not something that they took too seriously in the New South Wales Corps. But he would never have been permitted to have - I mean for a while this convict woman was the Lt.-Governor's wife [for a couple of months] in New South Wales. He would never have been permitted to have a woman like that as his acknowledged wife, and his children would have had no status at all. So there is that.

And it is the same with John Macarthur who was the Grand Man of colonial Australia but in England, of course, he'd be nobody because his father was a bodice-maker. 'Jack Bodice', his nickname was. So one of the things that is decidedly different about New South Wales and then later the other colonies of Australia, there really is no colonial elite of the kind that develops in America because they are either ex-convicts and so therefore indelibly marked or they are people who managed to 
buy their way into regiments which gets them into Australia. I mean, what more can you say? And so it is that the early connection to the American Revolution is not insignificant, because some of the lessons learned by the imperial overlords trickle down. The most, probably the first and most important one is this: There will be no slavery. Now that may seem - if you would say that to Australians they would be wondering why you would bother to make the point: because it sort of would never cross their mind, not being students of slavery like me, that it's the obvious thing to turn one of these colonies into a slave colony. But from the outset - and certainly Arthur Phillips was absolutely determined about this and with support from [Evan] Nepean - there will be no slavery.

Now, of course, you could argue that having people work in chains and whipping them with a hundred, with a thousand lashes is pretty well akin to it. But after a few years they were free, they were given land, they could make their own lives, they could return to Britain as we know from reading Great Expectations [by Charles Dickens]. But the New South Wales Court, John Macarthur in fact does try to introduce a system whereby the convicts become, are actually slaves though they weren't sold as such as they were in the American colonies. And they will have none of this: There will be no slavery. And once people have served their time, nominally at least, they are members of - and their children are - freeborn from the word go, and do not suffer any ill effect of being the children of felons. This is quite significant in that it doesn't develop a resentful and rebellious population, apart from the poor downtrodden Irish, who are just treated like animals, basically. I was so shocked when I started to read the way in which - when the Third Fleet arrived - those Irish convicts had been treated, treated worse than animals, and the way in which they were spoken about, as if they were subhuman in some way. But this is a deep British prejudice against the Irish, this isn't anything to do with the fact that they are convicts. But even the downtrodden Irish, apart from Ned Kelly and a few others, don't develop a strong resilience, [i.e.] resistance.

And so, Australia of all of the British colonies has always struck me as the most quiescent. The most forlorn, tugging, which is curious given that it is - it was not made by pre-settlers. It wasn't made by people who struck out from Britain to create a new Commonwealth, or to create a City on a Hill, it was made by forced labour, in the majority of cases by people who were forced to go there, under horrendous circumstances. And yet all the [research] work that has been done on the convicts makes it very clear: that they fared so much better. Should they happen to survive the voyage, and the first six months of colonisation, of scurvy, ill treatment and various things? They were fed so well, and they were; they fared so much better than they could possibly have done as free people in Britain, and more importantly, their children did spectacularly well. I mean one of the interesting things, the Scottish prisoners, who arrive are all basically under five feet, but their children are six feet and above, they just shoot up to the size that Scots are mentally.

\section{Laughter}

Cassandra Pybus: The Scots being a tall race - and so the general effect is one of being a basically egalitarian society in which the elite is transitory. They circle around the Empire, the elite is the imperial elite. That means you are not very self-conscious. They are not developing an ego of rebellious colonial underclass or a haughty colo- 
nial elite. The closest you get to a haughty colonial elite is 'Jack Bodice' or Macarthur. And you know, he understands. And George Johnston also. They understand only too well that they owe everything to their patrons in England. And then as long as they are off in Australia with their convict wives (not that John Macarthur has got a convict wife), but with their dubious backgrounds, and so forth, their patrons will look after them and look after their interests. But they shouldn't come back to England and expect to have a place in that society. I think that's one of the important things about this; this thing that has puzzled these radical-strain historians: Why Australia is so well behaved, so quiescent. Why, it constantly goes off to fight imperial wars! It couldn't wait, those colonials couldn't wait to get off to fight. I can't remember which is the first ridiculous episode that they go off to fight in. And even today, [27 ${ }^{\text {th }}$ September, 2014] our current conservative prime minister, following in the footsteps of John Howard, an earlier conservative prime minister, has very determinedly defined the Australian character in terms of its involvement in British overseas-wars.

Andrew O'Shaughnessy: There used to be a bad-taste English joke: "That there is one thing about the next war: A lot of Australians will get killed".

\section{Laughter}

Cassandra Pybus: And we're proud of it.

Andrew O'Shaughnessy: It's partly because also there is a constant influx of people from England. I was very struck with the First World War statistics, such a high percentage were actually born in Britain. And so migration is constant. Would you say, though, that this distrust of the leaders may have been one factor why they didn't encourage loyalists to settle in Australia, as sort of free Englishmen?

Cassandra Pybus: I think that something that Maya Jasanoff put her finger on and she is probably right, and I found it myself, too, - that the British are deeply distrustful of the loyalists. They don't really want them in their own backyard and they are not really keen on sending them anywhere else. I mean, to come back to the loyalists, it's another thing, the reason they don't first send convicts to Australia: They send them to the west coast of Africa. And even before that, they tried to send them to British Honduras and Nova Scotia, and that doesn't work out for piles of reasons, and so then they hit upon the bright idea that they'd send them to the west coast of Africa.

No, they basically sent them to the slave ports, the forts on the west coast of Africa where they work for a brief time before they die. You know, alongside enslaved Africans. And to the horror of the commander of Cape Coast Castle, the Africans see white men in chains, being beaten and made to work - what are they? - we'll have no control over them! - we can't have that! But that wasn't what stopped them doing it.

Basically, what stopped them doing it was that some of them came back. I mean those that survived. I mean most of them, they died. But some of those who managed to get back to England from the west coast of Africa, were then promptly put on the First Fleet and sent to Australia. James Matra, who was on Cook's first voyage had gone to Evan Nepean - I think it was Nepean - and said: "The loyalists - You know, we've got to find a place for the loyalists. We should send them to this wonderful place that Banks has described as being; you just stick a piece of corn in the ground and it goes wild, it's so fertile". And they weren't interested in doing any- 
thing for the loyalists, and in fact they didn't want to have a colony that was going to be settled by loyalists because they were tainted by the American spirit.

Andrew O'Shaughnessy: They were just as troublesome.

Cassandra Pybus: Just as troublesome. But there was somewhere that you could send your convicts where they wouldn't come back!

\section{Laughter}

Cassandra Pybus: They couldn't come back! And who cared whether they will die? That was the least of their concerns. And basically, liberals in Parliament were outraged at the idea that you were going to send people all the way to Australia because, you know, it was a death sentence.

You may as well hang them. The problem was, you couldn't hang them all. You talk about the Enlightenment, and there was a bit of that, but fundamentally, it was a logistical problem. You simply couldn't hang all the people that had capital sentences. As it was, there were people strung up on giblets all around them. You couldn't hang them all. If they all went to Australia and died...

Jennifer Anderson: Problem solved.

Cassandra Pybus: Or, you gave them picks and shovels and said: "Go become farmers". Taking up these pick-pockets and whores off the streets of London and send them off to New South Wales to become farmers. The fact that it worked is a miracle. It is extraordinary. And it is down to, a lot of it is down to Arthur Phillip: that it did work. Because basically he ensured that - and again, here's that whole business about following the Word of God - everyone got the same ration, which in the eighteenth century is extraordinary.

Jennifer Anderson: Pretty amazing.

Cassandra Pybus: Extraordinary thing. And again, when the New South Wales Corps arrived, they really wanted to put an end to that. They can't do it until Phillip is gone, then they got a more pliable governor. So there is that kind of egalitarianism, which for all who refer it to the American Revolution, there never was in America. But it's the egalitarianism of the bottom of the barrel. Basically, they were all the bottom of the barrel in one way or the other. They were all 'riff-raff'. Some of them are free 'riff-raff', and some of them are convict 'riff-raff'. And some of the convicts are elite as well. But not many of them. And they are so tainted by the fact that they have been convicted that their elite status is deeply undermined as far as going back to Britain is concerned. So, making sure that New South Wales and then the subsequent colonies do not become like America is part of the imperial project, there's no doubt about that.

Jennifer Anderson: One thing I wanted to come back to with my whalers, is that the American Revolution has a big impact, in particular in the wake of it where you see England trying to reassert control over the Empire, in particular trying to close down trade with these former colonies. And so one of the first things they do, is they ban American ships (and that is mainly American whalers) from Australian waters. And there's an immediate upcry about that in Australia because they want that, they want...

Cassandra Pybus: They want the rum. 
Jennifer Anderson: They want the rum. And they want that trade engagement. Yeah, and so there is that impact, where you see this faraway policy-making body imposing economic policies of the same sorts that had caused problems in North America. So the lesson wasn't particularly learned there. But that reverberates, of course, for these whalers back in New England, in two dimensions. Not only is it cutting off their access to these Australian areas that they had been traversing now for many years. It also in a sense interrupts their most important market, i.e. London and England, for their whaling products. And there is a wonderful attempt by John Adams, who was serving there in a diplomatic role to try and convince Parliament of their misguided policies by basically telling them: "The streets of American cities are all lit with whale oil. Do you want to be in the dark here in London, with thieves and villains running in the streets?" And apparently they were okay with that because they persisted in this policy for quite a few years, to the extent that these Nantucket whalers who had always been in a very ambivalent spot, especially during the Revolution, basically suspected by both the Americans and by the English of being disloyal, - they tried to be neutral - they're Quakers, were hard up. On top of having these trade connections to England and to the new United States. So, there's actually a group of whalers who go to England and try to convince - this is under Pitt - to set them up in a British territory so they could become British whalers. And that made them really popular in the United States...!

\section{Laughter}

Jennifer Anderson: And interestingly, one of the reasons, supporting this restrictive policy, was: "Well, how are we ever going to develop as good a British whaling corps if we don't support British whalers and exclude these Americans?" Who, for a lot of reasons you can discuss, were more adept at whaling and producing a better product. And they tried to negotiate a deal to either settle in England, they discussed Nova Scotia, they discussed a couple of possible different locations for this new English whaling colony. Finally, they get fed up that the English aren't meeting all of their demands and they go to France and establish their new whaling colony which is short-lived in the end, thanks to the French Revolution. But it's very interesting how these different politics kind of play out from one locale to another, across this vast space.

Therese-Marie Meyer: I would like to open this point to the discussion. One comment was, I think, straight about what you said about the whaling crews being so mixed ethnically, and about the American pernicious spirit that they're delivering. Because obviously, according to the literature, the spirit can be both: It can be wrong but it can also be the experience of that kind of mixed ethnic American 'riff-raff' intermingling probably too closely with your own 'riff-raff'. And far more closely than you actually want.

Jennifer Anderson: Cosmopolitan.

Therese-Marie Meyer: Yes. Obviously that does not reverse this process. There are books...

Cassandra Pybus: Two authors.

Therese-Marie Meyer: I do not know whether egalitarianism is the better word. But it is something of a likeness that these people, the 'riff-raff', the sailors and the whaling crews and the convicts would recognize amongst themselves. If only either 
of them would want it. And that they are all, in a way, either of them, transported elsewhere. Quite a lot of sailors, not just the Navy, but even merchant sailors - you did have them 'press-ganged', regularly in the Navy, right? But quite a lot of sailors in the merchant ships were also spirited away, or had been 'shanghaied', as the latest movement says. So they were not actually where they wanted to be. Neither were the convicts. None of them were where they wanted to be. Soldiers very much were not where they wanted to be either. I am just reminded of the Hessian Soldiers bursting into tears during the American Revolution. They were not where they wanted to be, very definitively. Much to the puzzlement of some Americans who saw them. So I think, could you comment on that maybe - on the similarities that seem to open up here?

Andrew O'Shaughnessy: What I have are two books, this well-known one by Vincent Brown, he is an African-American scholar, The Reaper's Garden. And ManyHeaded Hydra [by Peter Linebaugh and Marcus Rediker], they have got a lot of people there together who do not belong with each other.

\section{Laughter}

Andrew O'Shaughnessy: I don't know. You may dismiss them as all 'riff-raff' but they are very aware of distinctions between them, especially racial distinctions. So in many ways one might feel retrospectively, they should have been allies. But you feel that, too, often in the American South, almost to the present, the very poor whites and blacks want to feel some common mission. But it has been possible to divide them... the classic divide and rule. The status of whites was dependant on the sense that there was someone underneath, below them.

Jennifer Anderson: I think that I agree with what you are saying, and at the same time there is sort of a counter-current where you see these moments of opportunity that emerge for people, as you were describing, who would never have had possibilities in other places and times. And whether it's the Hessian Soldier who stays and becomes a wealthy Pennsylvania landowner. Or, I mean, I am thinking about my woodcutters in Belize. Many of them were convicts. Many of them got wealthy cutting down mahogany trees in South America and they are shipping them to Australia to make fancy furniture, in places like that deforested scene Tess showed. So there is this, it sets the whole world in motion, people and stuff and natural resources. It's such a remarkable period for that, I think.

Cassandra Pybus: Certainly one of the things that I picked up very early on when people started to ask me about their ancestors, you know, who must have been African, and how to explain this, was: These were whaling ships that came first into Sydney and hugely into Hobart, into Van Diemen's Land. There, I've got pictures of the River Derwent, it's just, a forest of masts, and they are all American whaling ships, with their highly mixed racial crews. When they got to New South Wales they realized that there was no slavery. So this was the one place in the whole maritime world where they could jump ship, and they did. And so in the Rocks in Sydney (and there is a little area just like the Rocks in Hobart, too): there were these marooned African-American communities. And you find them all the way through the Pacific apparently, according to [the maritime historian] W. Jeffrey Bolster [Black Jacks]. Then there is the other issue about the whaling ships and their involvement with Indigenous people all through the Pacific. They were there in New South Wales by the time 
the First Fleet arrived. They'd been working up and down the coast already. How many Aboriginal people had they co-opted into their project? I mean, once whaling started in Australia they co-opted Aboriginal people into it, so I am sure that the American whalers did so, and they probably continued also, at a later time: We know that Tasmanian Aboriginals ended up in New Zealand. There was that: The influence of the American whalers on those two maritime ports of Hobart and Sydney cannot be overestimated. And white Americans jumped ship there, too, because they saw that there was an opportunity to make a kind of life for themselves there that they would not have had in what was already a highly class-stratified society in New England.

Jennifer Anderson: I have a student right now who is working on the Hawaiian diaspora of native Hawaiians who get drawn into this and the whalers' [trade] - that trade becomes interconnected with some of the China trade involving sandalwood and furs from the Seattle-Vancouver area. And in each of those places there are people that leave traces behind and connections behind. It's amazing.

Cassandra Pybus: Speaking of marooned communities, there is, of course, a convict community, an escaped convict community in India. I think that seven years only after the First Fleet had arrived, the first escaped convicts had hidden away, [i.e.] secreted themselves into India.

Jennifer Anderson: The sailor that I mentioned ends up in New Zealand: He was a sailor who had basically committed a mutiny against his captain and then he and his co-conspirator were put off the ship, and, you know, there they are, they make a new life for themselves. And make the best of a bad situation.

Cassandra Pybus: To the point of your question - there is one thing I wanted to say, the native Americans on whaling ships: There was an outbreak of smallpox in the first eighteen months that decimated Aboriginal tribes around Sydney. And there has been a long discussion about whether or not it was, has been deliberately triggered or not, but there is no way that they couldn't have kept the variola alive on the First Fleet. So it was there already, smallpox, but only one person at Port Jackson died of smallpox. And that was a Native American.

Therese-Marie Meyer: Interesting.

Cassandra Pybus: Now, the question is: Who is this native American and what was he doing? A native American sailor on this awful whaling ship?

Jennifer Anderson: It could have been one of my New England Wampanoag, or a Shinnecock - absolutely, yeah.

Cassandra Pybus: So.

Jennifer Anderson: It's wild.

Cassandra Pybus: I think it is Collins who makes the observation. And you think: "How is it that we have gone for over two hundred years and nobody has asked the question: 'Who is this native American? What is he doing in Port Jackson?'" And you know, that is exactly what we are talking about: This extraordinary polyglot. To that extent Marcus Rediker and his co-author [Peter Linebaugh] are right about the Many-Headed Hydra, it's just a fact, place this. This polyglot kind of maritime Australia, being at the bottom of the world and being an island and being hugely influenced by maritime currents of all kinds. And it means that you do get this kind of transient underclass. Transient underclass fetches up there quite comfortably. 
Therese-Marie Meyer: I don't know which one of you [was the first....].

Audience Question: Okay, I am trying to collect my thoughts. Because I thought we feel very different: [I] fit here, under the level of space - of spacial explorations, and on the one hand there are such things as the concept of the realm, which you mentioned, the concept of the utopian city, Georgia, and on the other hand we have a maritime region that is hunted for whales. Which does not actually concentrate necessarily on one particular spot, as you explained already but it actually rose across the seas. What I was wondering in the first place, is: Can we in some way, for the American whalers, use the border myth that extends over the borders of that country, to that, possibly newly established "country" in the maritime realm - unlike those penal settlements which are constricted to one particular spot in Australia. Can such mythical categories again also reflect on the way, as of course the British fleet followed particular routes? I would suspect, rather than roving across the seas...

Therese-Marie Meyer: Exactly.

Audience Question: As they have been driven away, as they are trying to get away from routine.

Jennifer Anderson: I can speak to that because in preparation for this I was inspired to go and read some actual whaling logs to see what they had to say about Australia. And I was reading a particularly interesting - not a log say - but a diary that had been written from a slightly later period by the wife of a whaler. She is describing the route that they took. And she describes coming up sort of around basically between New Zealand and around the west side of Australia, and she is describing the space and she says something to the fact, "Well, we weren't really interested in Australia", and I was like: "Well, that's not helpful" and I am like "Wait a minute", and: "Doesn't that tell you how they are perceiving the space?" They are interested in the watery realm, that is their hunting-ground, and the land is peripheral to them, in so far as it is their support, you know, they would stop off to get fresh supplies, or water, or wood. But they are conceptualizing the space completely differently than somebody who is coming with an eye towards settlement or so.

Audience Question: At some point the penal colony actually stopped existing. ... Did they go for the same route? Up north, west, south? In the respective [carriers] in which they had landed? How did they sort of map their new world?

Andrew O'Shaughnessy: What is the country about?

Audience Question: How did they sort of map their new space, was that dictated by land speculators who had land to sell?

Cassandra Pybus: No, well, I suppose there was always an interest in finding, in getting the sense and finding all around Sydney, and finding decent farming country. But basically it was organised explorations from the very beginning. And then the convicts were forever making themselves boats to find an escape and they mapped a lot of the northern coast. They would get up there and find out what was there; and then be driven out for one reason or another. But the way out, obviously, is by boat. And so there is this constant attempt to steal boats, or to make boats, and, you know, you only have to look at the map to see what kind of boat you [will] need.

The most famous one is the one that gets to Batavia. A family basically managed to steal a boat and get all the way to Batavia, Indonesia. But, generally speaking, this is unsuccessful. Because there are not that many free settlers and it is a vast amount 
of land around Sydney, which doesn't really have anybody left on it because they have all died of smallpox. They sort of just parcel out small amounts of land. There is not the sort of pressure to expand that you might expect. Exploration is a very kind of individualistic thing in Australia. You get these kind of heroic explorers who set out to find what is there. And they find - what do they find? Desert. And Aborigines who spear them.

Audience Question: We were talking about egalitarianism under Arthur Phillip who put out the same rations to everyone, but from the very little bit I have read: His soldiers seemed to be very discontent with that. And basically, to be numbered with convicts, and be told they are worth as much as a convict? I was wondering, how it was compared to New England where society was stratified already.

I would have argued it was not an egalitarian society that was established. ... but as soon as it was possible through the circumstances that people would really diversify and would have social stratification and do it by whatever means possible. So you have different powers, going against each other, at different ideas I want to elaborate a little bit. Already in 1830, you have got people who would not have had a chance in England, definitely, but who are even more posh, more well-mannered, who look at the clothing much more exactly than they would have in England because they knew they have to give some signification of 'We are different'. So that you've got a new kind of elite, and not this egalitarianism of settlers, soldiers, convicts.

This basically disappears as soon as there is a means to do so. So it is pretty much a nice idea but it happens to be a different time of the founding of a nation where you would not just be that equal. It just looks like it because there are similarities. You are welcome to disagree but...

Cassandra Pybus: No, I agree with you entirely, I mean it is human nature, let's face it, to want to distinguish yourself as being richer or better or something. Well, the point I was trying to make is, it's not kind of codified. I mean, George Johnston's wife is a convict and nobody holds that against her in New South Wales. In the eighteenth, in the late eighteenth and early nineteenth century that is unthinkable, really. And one of the uppermost people, Simeon Lord, who is probably in urban Sydney the richest man, is an ex-convict with very lowly beginnings in England. And so the thing is, money talks, nobody is suggesting for one moment that that is not the case.

But there is not what you get in Virginia - Virginia being the place I am most familiar with of the British American colonies - you get a colonial aristocracy there. And that doesn't happen in Australia. And you get it in the Canadian colonies, too. That there is not an attempt to create a kind of hereditary elite. But money talks, there is no doubt about that. And of course, if you've got money, if you've got it, flaunt it!

Jennifer Anderson: Did distinctions emerge between people of mixed race and as you say are there differences between native-born and second-generation Creole the way you have in New Spain? Those kinds of distinctions?

Cassandra Pybus: The distinction is made and it is very clearly made and I claim it is no racial distinction, the distinction between everybody else and the Indigenous people.

Jennifer Anderson: Then that is not a regional distinction. 
Cassandra Pybus: Because it is not. If it is a racial distinction, it is a distinction about indigeneity, and not skin colour. Because otherwise you can't explain the people who are dark-skinned and who are not discriminated against, in any way. The expectation is, that they are. But they are not. And so, I mean you think: What is it about Aborigines? Well, the thing is the Aborigines have got something that the newcomers want. So they turn them into kind of vermin.

Jennifer Anderson: But do you get a mixed population?

Cassandra Pybus: No, you don't. Not very much at all. For a start.

Jennifer Anderson: That is very unusual.

Cassandra Pybus: The Pacific Islanders, they would give their women, ... so . The first kind of tension that happens between the Indigenous people and the colonial ones, is over women. And so inevitably there is some conflict, especially as the Aboriginal people become weaker and more dependent. There is much more exploitation of the Aboriginal women then. But there is very little evidence of mixed-race children.

Jennifer Anderson: In just about every other colonial context you get these individuals who are sort of in-between kind of people, who are of mixed race. And they often emerge as a sort of third class, between the native people and the colonisers.

Cassandra Pybus: Well, again, the children of Aboriginal women are likely to stay with the Aboriginal mother and within the tribe and that went well into the twentieth century when the Governors intervened and would start taking them away. So there is not a mestizo class that develops in Australia, no.

Audience Question: Why not go native?

Cassandra Pybus: Some people did that.

Audience Question: Sorry, it basically boils down to the making of a nation. You have different people from different societies, basically the outcasts of their times, exiles to Australia...

Jennifer Anderson: I am not sure they wanted to assimilate all these newcomers.

Audience Question: Yes but they were all, in a way, newcomers. Why not?

Jennifer Anderson: In the Native American context there were, especially among Algonquin communities, there were traditions even before colonisation of how to assimilate people from outside groups. There was a great deal of ritualised adoptions, for example. One of the interpretations, when John Smith arrives in Virginia and Pocahontas intervenes to supposedly save his life, is that he did not realise that he was being integrated into their community. So I don't - were there similar mechanisms? It sounds to me like the Aborigines were more assimilating.

Cassandra Pybus: One of the things you need to understand is the thought of the isolation of the island-continent at the bottom of the world: in that the Indigenous people had no concept of there being other people who might come and want what they had. And so first they are kind of curious, interested, curious. But then it becomes apparent that these people are going to take their hunting grounds, and that is when you get the resistances lead be Pemulwuy.

But the problem is: the smallpox decimated the tribes around Sydney and that weakened the capacity to fight back. And from then it is like, it's almost like a constant pushing back, pushing away, on the understanding that the country is so vast, 
and these are nomadic people, and they don't water crops, and they don't put up fences and all the rest of it.

Audience Question: It's a question of establishing territory. I was raised as an Australian so I know that others consider Aboriginal men and women as inferior. Whenever you see a woman who is not clothed and she happens to be alone or see a man who is considered wild and he speaks a completely different language... because they are "so inferior"...

Cassandra Pybus: Well, yes, there has been a whole argument about it, actually. The theory of 'Terra Nullius', which is - the land is empty. Sure, it's got these people on it, we can see who they are, but they are not using the land. There is books and books and books written about this thing because at the time the concept of law was being codified to consider issues about: Who actually owned this place?

And so this theory of 'Terra Nullius' was very convenient which was: Nobody was owning it because they weren't using it. And that again is a good enough argument for considering them to be like wild animals and therefore you can just kill them. And you know, when they get into the way, I mean you do not go out and eradicate the foxes, the wolves because they are there. You are starting to eradicate them because they are killing the sheep. And it was the same thing. Once they started fighting back of just trying to get some food, then they became vermin.

But the point that I was trying to make about not being racial issues - that racism as we think about it, as we talk about it - tends to be about skin colour. Black versus white. That is not what the issue is. This is about, so, sure, they were black, and they were different, they are wild, they are savage, but basically the problem is that you've got to eradicate them or to completely subjugate them in order to have what they think they own, their land.

Therese-Marie Meyer: I just have to say this. Last night at dinner Cassandra was saying this: It is about one third of the officers who have been to America. And I was saying: No, it is far... far more.

So I thought, okay; and what Andrew was saying before, that this really has not been looked at and that indeed the experience of the American War was very different depending on what particular side... you were for or where at the time you were at. There was this massive difference between the war in the Caribbean and the war in the North: around Quebec. And at Yorktown versus the Southern States. And I was wondering: This seems to me crucial, what I looked at with David Collins. The way that Bunker Hill and what he experienced there influenced his actions in South Africa afterwards.

So please some of you historians, just find out where these worthy officers have been. You see I am going to throw this titbit at you, it's a titbit that is for all three of you. There's one man there who is actually an acquaintance of Governor Philip King, a man who has Evan Nepean speaking at his trial. King met him in Jamaica, when King was lieutenant on a ship: Ship got into a hurricane, was completely damaged and ended up in harbour for one year, stuck in Jamaica, in Kingston, they were repairing the ship. This was when they met. This man has Evan Nepean and Lord Nelson speaking at his trial. I am talking, pointing out what connects Edward Despard with King this far, who was at [the settlement of] Belize, which became British Honduras. 
Jennifer Anderson: Oh yes, I did a wider work on him.

Therese-Marie Meyer: Famously, at his trial he begged not to be sentenced but to be sent to Australia. And there is this lovely note, apparently, on his application, saying: Impossible. Particularly because, of course, Australia is teeming with naughty Irishmen and he's applied as an Englishman.

Jennifer Anderson: Ireland, he was involved in Ireland, too.

Therese-Marie Meyer: He'd be known, notorious down there. Which gets us back to the place of your colonial elite. You don't want that, you don't want a republican elite developing.

Jennifer Anderson: Oh, that would make a great book if this pirate goes down to Australia, raises hell. And he was married to a native woman. In today's Belize.

Therese-Marie Meyer: Yes. Exactly in former British Honduras. So I think that is a very interesting case that sort of points to the issue of where exactly were these people? As Governor King obviously did, when he came to Australia. He did not have the same kind of experience as George Johnston had or when he was in New York, or all that David Collins saw when he was at Bunker Hill.

Cassandra Pybus: No, not that I am aware of.

Jennifer Anderson: I am going to have to round up a grad student. Or I'll do it myself. It's so interesting.

Therese-Marie Meyer: So I have to say... There is a big pile of work to get into. Anybody else here who feels inspired to? Thank you very, very much.

Very inspiring for all of us. I am certainly teeming with ideas here. I hope you will continue tonight with those discussions. 